Available online at http://journal.stkip-andi-matappa.ac.id/index.php/histogram/index

Histogram : Jurnal Pendidikan Matematika 2 (2), 2018, 148-158

\title{
DESAIN PEMBELAJARAN KOOPERATIF BERBASIS TEORI BRUNER UNTUK MENINGKATKAN KUALITAS PEMBELAJARAN MATEMATIKA
}

\author{
Andi Yunarni Yusri ${ }^{1}$ Sadriwanti Arifin ${ }^{2}$ \\ STKIP Andi Matappa ${ }^{1}$ \\ STIE Mujahidin Tolitoli \\ * Corresponding Author. Email: yunarniyusri@gmail.com \\ Received: 1 September 2018; Revised: 21 September2018; Accepted: 27 September 2018
}

\begin{abstract}
ABSTRAK
Jenis penelitian adalah desain research yang bertujuan untuk mendesain pembelajaran, khususnya perangkat yang digunakan dengan model pembelajaran kooperatif berbasis teori Bruner pada pokok bahasan kubus dan balok yang meliputi Rencana Pelaksanaan Pembelajaran, Buku Siswa, dan Lembar Kerja Siswa. Subjek penelitian ini adalah siswa kelas VIII SMP Negeri 1 Labakkang sebanyak 30 orang. Prosedur desain yang digunakan siklus Mc. Kenney yang dipadukan dengan model Dick \& Carey yang meliputi 3 tahap, yaitu Preliminary design, Prototyping phase, dan assessment phase. Perangkat pembelajaran kooperatif berbasis teori Bruner yang telah didesain telah divalidasi dan direvisi tiga kali sehingga layak untuk digunakan. Hasil dari ujicoba terbatas menunjukkan bahwa perangkat pembelajaran kooperatif berbasis teori Bruner bersifat efektif dan praktis, yaitu (1) skor rata-rata yang diperoleh siswa pada tes hasil belajar adalah 76,87 dari skor ideal 100 dengan standar deviasi 12,43. Dimana 24 dari 30 siswa atau 80\% memenuhi ketuntasan individu yang menunjukkan bahwa ketuntasan klasikal tercapai; (2) dengan menggunakan perangkat pembelajaran kooperatif berbasis teori Bruner, siswa menjadi lebih aktif dalam proses pembelajaran ; (3) pada umumnya siswa memberikan respons positif terhadap kegiatan pembelajaran. Jadi berdasarkan uraian tersebut, dapat disimpulkan bahwa hasil desain pembelajaran pembelajaran kooperatif berbasis teori Bruner di kelas VIII SMP Negeri 1 Labakkang berkualitas.
\end{abstract}

Kata kunci: Pembelajaran Kooperatif, Teori Bruner, Kualitas Pembelajaran

How to Cite: Yunarni, A., Arifin, S. (2018). Desain Pembelajaran Kooperatif Berbasis Teori Bruner Untuk Meningkatkan Kualitas Pembelajaran Matematika. Histogram: Jurnal Pendidikan Matematika, 2(2), 147-158. doi: http://dx.doi.org/10.31100/histogram.v2i2.233

\section{Permalink/DOI:}

http://dx.doi.org/10.31100/histogram.v2i2.233

\section{PENDAHULUAN}

Mata pelajaran Matematika perlu diberikan kepada semua siswa mulai dari sekolah dasar untuk membekali siswa dengan kemampuan berpikir logis, analitis, sistematis, kritis, dan kreatif, serta kemampuan bekerjasama. Kompetensi tersebut diperlukan agar siswa dapat memiliki kemampuan memperoleh, mengelola, dan memanfaatkan informasi untuk bertahan hidup pada keadaan yang selalu berubah, tidak pasti, dan kompetitif (Depdiknas, 2006:345). Kualitas pembelajaran dalam hal ini proses belajar mengajar di dalam kelas 


\section{Histogram: Jurnal Pendidikan Matematika, 2 (2), 2018 - 149 Andi Yunarni Yusri , Sadriwanti Arifin}

diarahkan pada kemampuan anak untuk menghafal informasi, otak anak dipaksa untuk mengingat dan menimbun berbagai informasi tanpa dituntut memahami informasi yang diingatnya itu untuk menghubungkan dengan kehidupan sehari-hari. Ketika anak didik kita lulus dari sekolah, mereka pintar secara teoritis, tetapi miskin aplikasi.

Berbagai upaya untuk meningkatkan kualitas pembelajaran matematika telah banyak dilakukan, baik oleh pemerintah maupun oleh berbagai pihak yang peduli terhadap pembelajaran matematika sekolah. Berbagai upaya tersebut antara lain dalam bentuk: (1) penataran guru, (2) kualifikasi pendidikan guru, (3) pembaharuan kurikulum, (4) implementasi model atau metode pembelajaran baru, (5) penelitian tentang kesulitan dan kesalahan siswa dalam belajar matematika. Namun berbagai upaya tersebut belum mencapai hasil yang optimal, karena berbagai kendala di lapangan. Oleh karena itu, diperlukan suatu tindakan untuk memperbaiki kualitas pembelajaran matematika.

Lebih lanjut berdasarkan pengalaman guru-guru matematika di SMP Negeri 1 Labakkang dalam mengajarkan materi bangun ruang, siswa mengalami kesulitan memahami konsep bangun ruang. Siswa sulit untuk menentukan bidang diagonal sebuah bangun ruang. Kesulitan lain yang biasa ditemukan adalah menyelesaikan soal bangun ruang yang diaplikasikan dalam kehidupan sehari-hari, mencari sisi dari bangun ruang yang ditentukan volumenya, menyelesaikan soal bangun ruang dalam bentuk soal cerita.

Adapun salah satu penyebab kesulitan pembelajaran dan pembahasan konsep bangun ruang adalah, bangun ruang merupakan hasil proses abstraksi dan idealisasi dari benda-benda konkrit berdimensi tiga yang memiliki ukuran panjang, lebar, dan tinggi. Namun gambar bangun tersebut pada bidang gambar merupakan proyeksi bangun ruang tersebut pada bidang gambar. Pada gambar kubus misalnya, dapat terjadi suatu ruas garis yang kelihatannya berimpit, namun pada kenyataannya tidak berimpit. Pada gambar dapat terjadi suatu bidang yang tergambar sebagai jajar genjang namun pada kenyataannya berbentuk persegi. Hal-hal seperti inilah yang harus diantisipasi oleh para guru matematika. Salah satu alternatif yang dapat meningkatkan kualitas dan motivasi siswa untuk belajar matematika yaitu melalui belajar penemuan. Teori belajar penemuan merupakan suatu pendekatan dalam belajar, dimana siswa berinteraksi dengan lingkungannya dengan jalan mengeksplor dan memanipulasi obyek, bergulat dengan sejumlah pertanyaan dan kontroversi atau melakukan percobaan. Ide dasar dari teori ini adalah siswa akan mudah mengingat suatu konsep jika konsep tersebut mereka dapatkan sendiri melalui proses belajar penemuan. Lebih lanjut, Bruner juga memperkenalkan konsep perkembangan 


\section{Histogram: Jurnal Pendidikan Matematika, 2 (2), 2018 - 150 Andi Yunarni Yusri, Sadriwanti Arifin}

kognisi anak-anak yang mewakili tiga bentuk representasi: representasi enaktif, ikonik dan simbolik. Pada tahap enaktif misalnya, pengetahuan anak diperoleh dari aktivitas gerak yang dilakukannya seperti pengalaman langsung atau kegiatan konkrit. Tahap representasi ikonik adalah masa ketika pengetahuan anak diperoleh melalui sajian gambar, atau grafis lainnya seperti film dan gambar statis. Sedangkan tahap representasi simbolik adalah suatu tahap dimana anak mampu memahami atau membangun pengetahuan melalui proses bernalar dengan menggunakan simbol bahasa seperti kata-kata atau simbolisasi abstrak lainnya.

Lebih lanjut, Bruner juga memperkenalkan konsep perkembangan kognisi anakanak yang mewakili tiga bentuk representasi: representasi enaktif, ikonik dan simbolik. Pada tahap enaktif misalnya, pengetahuan anak diperoleh dari aktivitas gerak yang dilakukannya seperti pengalaman langsung atau kegiatan konkrit. Tahap representasi ikonik adalah masa ketika pengetahuan anak diperoleh melalui sajian gambar, atau grafis lainnya seperti film dan gambar statis. Sedangkan tahap representasi simbolik adalah suatu tahap dimana anak mampu memahami atau membangun pengetahuan melalui proses bernalar dengan menggunakan simbol bahasa seperti kata-kata atau simbolisasi abstrak lainnya.

Dengan demikian teori belajar penemuan Bruner sangat menyarankan keaktifan siswa dalam proses belajar secara penuh untuk bisa menemukan kembali berdasarkan interaksi yang dilakukannya dengan lingkungannya melalui serentetan pengalamanpengalaman yang lampau.

Belajar melalui penemuan berpusatkan pada siswa. Belajar menemukan, menyebabkan siswa berkembang potensi intelektualnya. Dengan menemukan hubungan dan keteraturan dari materi yang sedang dipelajari, siswa menjadi lebih mudah mengerti struktur materi yang dipelajari. Siswa lebih mudah mengingat konsep, struktur atau rumus yang telah ditemukan (Rochaminah, 2010:9).

Maka peneliti tertarik untuk mengadakan penelitian tentang Desain Pembelajaran Kooperatif Berbasis Teori Bruner Untuk Meningkatkan Kualitas Pembelajaran Matematika di Kelas VIII SMPN 1 Labakkang. Berdasarkan latar belakang yang telah dikemukakan di atas, maka tujuan penelitian ini adalah untuk mengetahui: (1) "Bagaimana proses dan hasil desain pembelajaran kooperatif berbasis teori Bruner di kelas VIII SMP Negeri 2 Labakkang yang berkualitas?” 


\section{METODE PENELITIAN}

\section{A. Jenis Penelitian}

Jenis penelitian ini adalah desain Research yaitu studi sistematis tentang perancangan, pengembangan dan pengevaluasian intervensi pendidikan sebagai solusi untuk masalah kompleks dalam praktek pendidikan, yang juga bertujuan untuk memajukan pengetahuan kita tentang karakteristik dari intervensi dan proses perancangan dan pengembangan mereka. Desain yang dimaksud dalam penelitian ini adalah desain pembelajaran kooperatif berbasis teori Bruner untuk meningkatkan kualitas pembelajaran.

\section{B. Subjek Penelitian}

Penelitian ini dilaksanakan di Kelas VIII SMP Negeri 1 labakkang tahun pelajaran 2018/2019, dan subjek penelititannya adalah siswa kelas VIII dengan jumlah siswa 30 orang yang memiliki kemampuan yang heterogen. Pemilihan SMP Negeri 1 Labakkang berdasarkan pertimbangan bahwa sekolah tersebut mempunyai kualitas menengah artinya SMP Negeri 1 Labakkang termasuk sekolah yang bukan terbaik dan bukan yang terjelek berdasarkan nilai ujian nasional yang berada dalam kategori sedang.

\section{Instrumen Penelitian}

Untuk mengumpulkan data dalam rangka penelitian ini, digunakan instrumen penelitian berupa lembar observasi (pengamatan), angket respons siswa dan tes hasil belajar. Berikut uraian tentang instrumen tersebut.

1. Lembar observasi (pengamatan)

Lembar observasi digunakan untuk memperoleh data yang berkaitan dengan kegiatan pembelajaran selama penelitian. Lembar observasi terdiri dari: Lembar observasi (pengamatan) pengelolaan pembelajaran, digunakan untuk memperoleh data mengenai guru dalam mengelola pembelajaran kooperatif berbasis teori Bruner aktivitas siswa selama proses pembelajaran. Pengamatan dilakukan oleh seorang pengamat dalam setiap kali pertemuan. Instrumen yang digunakan untuk mengamati kemampuan guru dalam mengelola pembelajaran adalah lembar pengamatan pengelolaan pembelajaran 


\section{Histogram: Jurnal Pendidikan Matematika, 2 (2), 2018 - 152 Andi Yunarni Yusri, Sadriwanti Arifin}

\section{Angket respons siswa.}

Angket respons siswa disusun sendiri oleh peneliti. Sebelum digunakan, divalidasi oleh ahli/praktisi, kemudian direvisi berdasarkan saran-saran validator. Angket respons siswa digunakan untuk mengumpulkan data mengenai respons siswa terhadap pelaksanaan pembelajaran dan komponen pembelajaran (materi, lembar kegiatan siswa, tes hasil belajar, suasana pembelajaran di kelas, dan cara guru mengajar, serta minat siswa untuk mengikuti pembelajaran dengan pendekatan yang sama pada pembelajaran berikutnya). Siswa memberikan tanda cek list $(\sqrt{ })$ pada kolom yang tersedia untuk setiap pertanyaan yang diajukan.

3. Tes hasil belajar

Tes hasil belajar disusun sendiri oleh peneliti. Sebelum digunakan, divalidasi oleh ahli/praktisi, kemudian direvisi berdasarkan saran-saran validator. Tes hasil belajar digunakan untuk memperoleh informasi tentang kemampuan matematika siswa sebelum proses pembelajaran serta penguasaan siswa setelah proses pembelajaran. Tes ini disusun dengan mengacu pada konpetensi dasar dan indikator yang sesuai dengan kurikulum tingkat satuan pendidikan (KTSP), pada kegiatan ini dilakukan perancangan kisi-kisi tes hasil belajar, butir tes hasil belajar, alternatif jawaban, dan pedoman penskoran. Tes yang disusun merupakan tes yang berbentuk uraian/essai dengan alokasi waktu 2 x 40 menit. Sedangkan jumlah butir tes hasil belajar adalah enam butir soal. Indikator yang diukur oleh tes tersebut merupakan indikator produk.

Pemberian skor pada hasil tes ini dapat dikelompokkan dalam skala lima berdasarkan teknik kategorisasi standar yang ditetapkan oleh Departemen Pendidikan dan Kebudayaan (Depdikbud, 1999) yaitu:
a. Kemampuan $85 \%$ - $100 \%$ atau skor $85-100$ dikategorikan sangat tinggi.
b. Kemampuan $65 \%$ - $84 \%$ atau skor $65-84$ dikategorikan tinggi.
c. Kemampuan 55\% - $64 \%$ atau skor 55- 64 dikategorikan sedang.
d. Kemampuan $35 \%$ - $44 \%$ atau skor 35 - 44 dikategorikan rendah.
e. Kemampuan $0 \%-34 \%$ atau skor $0-34$ dikategorikan sangat rendah 


\section{Pengumpulan Data dan Validasi Data}

Adapun cara pengumpulan data yang dilakukan dalam penelitian ini adalah sebagai berikut:

1. Data mengenai kemampuan guru mengelola/melaksanakan kegiatan pembelajaran diperoleh dari lembar observasi (pengamatan) pengelolaan pembelajaran.

2. Data mengenai aktivitas siswa dalam kegiatan proses pembelajaran, diperoleh dari lembar observasi (pengamatan) aktivitas siswa.

3. Data mengenai respons siswa terhadap pembelajaran melalui penerapan pendekatan pemecahan masalah dengan latihan terbimbing diperoleh melalui angket respons siswa.

4. Data mengenai hasil belajar matematika siswa diperoleh dari hasil tes yang diberikan kepada siswa.

Data yang telah dikumpulkan dengan menggunakan instrumen-instrumen, seperti yang telah disebutkan pada bagian E, selanjutnya dianalisis secara kuantitatif dan diarahkan untuk menjelaskan kevalidan, keefektifan, dan kepraktisan perangkat pembelajaran. Data yang diperoleh dari hasil validasi oleh para ahli, dianalisis untuk menjelaskan kevalidan dan kelayakan penggunaan perangkat pembelajaran di kelas. Adapun data hasil uji coba di kelas digunakan untuk menjelaskan keefektifan dan kepraktisan perangkat pembelajaran (Darwis, 2007).

\section{E. Teknik Analisis Data}

Data yang terkumpul selanjutnya dianalisa secara kuantitatif dan kualitatif. Data yang dianalisa secara kuantitatif adalah data tes hasil belajar. Untuk analisa secara kuantitatif digunakan statistik deskriptif untuk mendeskripsikan kualitas pembelajaran matematika responden penelitian melalui pendekatan matematika realistik, yang terdiri dari nilai rata-rata (mean), rentang (range), nilai maksimum dan nilai minimum. Untuk analisa secara kualitatif diarahkan untuk menjawab:

"Bagaimana proses dan hasil desain pembelajaran kooperatif berbasis teori Bruner di Kelas VIII SMP Negeri 1 Labakkang yang berkualitas?" 


\section{HASIL PENELITIAN DAN PEMBAHASAN}

Pada bagian ini dikemukakan pembahasan hasil penelitian yang meliputi tiga hal, yaitu: (1) ketercapaian tujuan penelitian, (2) kendala-kendala yang ditemui, dan (3) kelemahan-kelemahan penelitian. Ketercapaian tujuan peneltian yang akan diuraikan adalah seberapa jauh tujuan penelitian yang direncanakan tercapai. Ketercapaian ini dikaitkan dengan kevalidan, kepraktisan, dan keefektifan perangkat pembelajaran kooperatif berbasis teori Bruner.

Kendala-kendala dalam penelitian yang akan dikemukakan, yaitu kendala-kendala selama proses desain pembelajaran, menyangkut tentang implementasi perangkat pembelajaran di kelas dan kesiapan-kesiapan yang diperlukan untuk memperoleh perangkat pembelajaran.

Kelemahan-kelemahan penelitian yang dikemukakan adalah kelemahankelemahan akibat keterbatasan penelitian, khususnya kelemahan pada proses uji coba. Selain itu diungkapkan pula alasan munculnya kelemahan-kelemahan dan alternatif solusi yang dapat ditempuh untuk mengurangi atau meminimalkan kelemahan tersebut. Pembahasan ketiga hal di atas dikemukakan berikut ini:

\section{A. Ketercapaian tujuan penelitian}

1. Kevalidan

Pada Bab sebelumnya telah dikemukakan mengenai uji kevalidan, berdasarkan alasan tersebut dapat disimpulkan bahwa prototipe/draft ( RPP, LKS,Buku Siswa, THB, angket respons siswa, pengamatan pengelolaan pembelajaran, dan pengamatan aktivitas siswa) secara keseluruhan telah memenuhi kriteria kevalidan.

Hasil penilaian ahli dan praktisi dalam bidang pendidikan matematika menunjukkan bahwa perangkat pembelajaran kooperatif berbasis teori Bruner ditinjau dari keseluruhan aspek sudah dapat dinyatakan valid, namun masih terdapat saran-saran perbaikan yang perlu diperhatikan untuk kesempurnaan perangkat, saran-saran tersebut meliputi (1) perangkat pembelajaran yang digunakan harus nampak unsur kooperatif yang berbasis teori Brunernya agar ada ciri khusus yang membedakan dengan perangkat pembelajaran yang lain, (2) penyajian materi pada perangkat pembelajaran harus disesuaikan dengan model pembelajaran yang digunakan, dan (3) hal-hal yang akan dikonstruk oleh siswa jelas pada setiap masalah-masalah kontektual yang disajikan. Setelah dilakukan revisi maka perangkat pembelajaran ini dapat digunakan dalam proses Copyright (C) 2018, Histogram: Jurnal Pendidikan Matematika ISSN: 2549-6700 (print), ISSN 2549-6719 (online) 


\section{Histogram: Jurnal Pendidikan Matematika, 2 (2), 2018 - 155 Andi Yunarni Yusri, Sadriwanti Arifin}

pembelajaran matematika. Selain itu penyajian materi pada perangkat tersebut merupakan penyajian dengan pengkonstruksian yang dilakukan oleh siswa sendiri. Pengkonstruksian yang dilakukan oleh siswa menyangkut materi kubus dan balok yang berbentuk pengetahuan deklaratif, prosedural, dan pengetahuan kondisional.

\section{Kepraktisan}

Secara teoritis, hasil penilaian ahli dan praktisi dalam bidang pendidikan matematika terhadap perangkat pembelajaran kooperatif berbasis teori Bruner menyatakan bahwa perangkat layak di gunakan dalam pembelajaran. sedangkan secara empirik, berdasarkan hasil pengamatan terhadap perangkat pembelajaran oleh dua observer menyatakan bahwa perangkat pembelajaran terlaksana dengan baik pada saat uji coba. Berdasarkan hasil penilaian pengamat, maka perangkat pembelajaran telah memenuhi kriteria kepraktisan.

\section{Keefektifan}

Pada Bab III telah dikemukakan kriteria keefektifan perangkat pembelajaran yang meliputi: (1) Tes hasil belajar, (2) aktivitas siswa, (3) respons siswa. Kriteria yang harus dipenuhi sehingga suatu perangkat pembelajaran dikatakan efektif adalah ke 3 kriteria tersebut harus terpenuhi. Berdasarkan hasil pengamatan dilapangan ke 3 kriteria terpenuhi, maka perangkat pembelajaran telah memenuhi kriteria keefektifan.

\section{B. Kendala-kendala yang dialami selama penelitian}

Dalam pelaksanaan penelitian ditemukan beberapa kendala yang dialami selama kegiatan, terutama dalam kegiatan uji coba perangkat pembelajaran kooperatif berbasis teori Bruner. Kendala-kendala yang dimaksud dikemukakan sebagai berikut:

1. Pada awal uji coba, siswa masih terkadang sulit mengubah kebiasaan belajar selama ini yaitu hanya duduk menyaksikan gurunya menerangkan. Mereka merasa kesulitan karena mereka yang harus aktif dalam pembelajaran. Mereka harus menemukan sendiri konsep dan lain-lainya yang diberikan pada LKS yang telah disediakan. Hal tersebut tidak biasa mereka lakukan sehingga pertemuan awal uji coba peneliti merasa kewalahan dalam mengarahkan siswa.

2. Perilaku siswa dalam belajar masih mengarah pada perilaku yang kurang baik. Perilaku tersebut antara lain: (a) kurang mempersiapkan diri mengikuti pelajaran, (b) malas mengajukan pertanyaan, dan (c) kurang berminat untuk belajar kelompok. 
Histogram: Jurnal Pendidikan Matematika, 2 (2), 2018 - 156

Andi Yunarni Yusri, Sadriwanti Arifin

\section{Keterbatasan penelitian}

Tujuan dari penelitian ini adalah untuk memperoleh desain pembelajaran kooperatif berbasis teori Bruner pada siswa kelas VIII SMP yang berkualitas. Model yang digunakan dalam penelitian ini menggunakan model Dick \& Carey. Melalui prosedur pengembangan model tersebut dihasilkan perangkat yang dikategorikan baik. Akan tetapi dalam penelitian terdapat beberapa keterbatasan, yaitu Ujicoba lapangan hanya dilakukan pada satu kelas saja yaitu di Kelas VIII SMP Negeri 1 Labakkang, untuk mendapatkan masukan yang lebih banyak seharusnya ujicoba lapangan tidak dilakukan hanya pada satu kelas saja akan tetapi diujicobakan pada beberapa kelas. Dengan keterbatasan yang ada ujicoba lapangan tersebut tidak dapat peneliti laksanakan dalam lebih dari satu kelas. 


\section{KESIMPULAN DAN SARAN}

Berdasarkan hasil penelitian dan pembahasan yang dilakukan, maka diperoleh kesimpulan dalam penelitian ini, sebagai berikut:

1. Proses desain pembelajaran kooperatif berbasis teori Bruner di kelas VIII SMP Negeri 1 Labakkang berkualitas. Desain pembelajaran kooperatif berbasis teori Bruner ini disusun mengikuti alur pengembangan Dick and Carey dan dilakukan secara bersiklus seperti yang digambarkan oleh McKenney, meliputi tahap, yaitu (1) preliminary research yang mencakup tiga langkah, yaitu: analisis kebutuhan dan analisis isi, kajian pustaka, dan pengembangan konsep atau teori kerja untuk studi; (2) tahap prototyping yang mencakup dua langkah, yaitu: mendesain perangkat pembelajaran, mendesain instrumen (lembar observasi aktivitas siswa dan guru, angket respons siswa dan tes hasil belajar); (3) tahap assessment yang mencakup dua langkah, yaitu: penilaian dan ujicoba. Berdasarkan hasil uji coba, dengan digunakannya perangkat dan instrumen pembelajaran pendukung desain pembelajaran menyebabkan meningkatnya aktivitas guru dan siswa serta respon siswa. Desain pembelajaran yang digunakan sesuai dengan desain pembelajaran yang dirancang.

2. Hasil desain pembelajaran kooperatif berbasis teori Bruner di kelas VIII SMP Negeri 1 Labakkang berkualitas. Berdasarkan hasil uji coba diperoleh rata-rata hasil belajar siswa diatas KKM (Kriteria Ketuntasan Minimal). 


\section{DAFTAR PUSTAKA}

Asri, C, B. (2005). Belajar dan Pembelajaran.Jakarta: Asdi Mahasatya.

Dahar, R.W. (1988). Teori-teori Belajar. Jakarta: Departemen P dan K Direktorat Jendral Tinggi Proyek Pengembangan Lembaga Pendidikan Tenaga Kependidikan.

Sudana, D, N. (1989). Ilmu Pengajaran Taksonomi Variabel. Jakarta: Departemen Pendidikan dan Kebudayaan Direktorat Jenderal Pendidikan Tinggi P2LPTK.

Depdiknas. (2006). Kurikulum 2004 Standar Kompetensi Mata Pelajaran Matematika Sekolah Menengah Atas (SMA) dan Madrasah Aliyah (MA). Jakarta: Depdiknas.

Heruman. (2007). Model Pembelajaran Matematika di Sekolah Dasar. Bandung: Remaja Rosdakarya.

Ibrahim, M. (2005). Pembelajaran Kooperatif. Surabaya: Pusat Sains dan Matematika Sekolah Universitas Negeri Surabaya.

Ismail. (1995). Kapita Selekta Pembelajaran Matematika. Jakarta: Proyek DIKTI.

Lie, A. (2005). Cooperative Learning. Jakarta: Grasindo.

Markaban. (2010). Model Pembelajaran Matematika dengan Pendekatan Penemuan Terbimbing. Yogyakarta: PPPG Matematika. Online. (http://p4tkmatematika.org/downloads/ppp/PPP_Penemuan_terbimbing.pdf).

Diakses tanggal 18 Juli 2018.

Nurdin, (2007). Model Pembelajaran Matematika yang Menumbuhkan Kemampuan Metakognitif untuk Menguasai Bahan Ajar. Disertasi tidak diterbitkan. Surabaya: PPs UNESA.

Uno, H. (2009). Desain Pembelajaran. Gorontalo: MOS Publishing. 